Tarbawi: Jurnal Ilmu Pendidikan p-ISSN:1858-1080 | e-ISSN: 2615-6547

Vol. 16, No. 1, Juli 2020, 59 - 70

\title{
Islamic Counseling Program to Resolve Personal, Social, Career and Academic Problems of Students
}

\author{
Eko Sujadi, Muhd. Odha Meditamar, Martunus Wahab \\ Institut Agama Islam Negeri Kerinci \\ E-mail: ekosujadi@iainkerinci.ac.id
}

\begin{abstract}
In spite of the legal basis for implementing guidance and counseling in higher education is not as complete and detailed as counseling services in primary and secondary education units, a number of regulations indicate that guidance and counseling services are an important element in the organization of college. This research aims to formulate a program of counseling services based on appropriate qur'ani values according to the expert and describe the frequency of usage of the counseling service program to resolve student problems. This developmental research is carried out using the steps of the ADDIE model (Analyze, Design, Development, Implementation, and Evaluation). The subjects of research trial consist of 3 experts and 3 product users (counselors), taken using the purposive sampling method. The analysis technique used is descriptive statistics and Kendall concordance coefficient tests. The results indicate that: (1) a counseling service program based on qur'ani values is considered appropriate to be given to students; (2) the usability level of qur'ani valuesbased counseling service programs is considered highly usable to be used as a reference in counseling services.
\end{abstract}

Keywords: qur'ani counseling service program, personal, social, career, academic

\begin{abstract}
Abstrak: Meskipun dasar legal mengenai pelaksanaan bimbingan dan konseling di perguruan tinggi tidak selengkap dan detail seperti pelayanan konseling di satuan pendidikan dasar dan menengah, namun beberapa peraturan mengisyaratkan bahwa pelayanan bimbingan dan konseling merupakan unsur penting dalam penyelenggaraan perguruan tinggi. Penelitian ini bertujuan untuk merumuskan program pelayanan konseling berbasis nilai-nilai qur'ani yang layak menurut abli serta mendeskripsikan tingkat keterpakaian program pelayanan konseling tersebut untuk mengatasi permasalaban mahasiswa. Penelitian pengembangan ini dilakukan dengan mempedomani langkah model ADDIE (Analyze, Design, Development, Implementation, and Evaluation). Subyek uji coba penelitian terdiri dari 3 orang abli dan 3 orang pengguna produk (konselor), yang diambil dengan menggunakan metode purposive sampling. Teknik. Analisa yang digunakan yakni statistic deskriptif dan uji koefisien konkordansi kendall. Hasil penelitian menunjuk.kan bahwa: (1) program pelayanan konseling berbasis nilai-nilai qur'ani dinilai layak untuk diberikan kepada mahasiswa; (2) tingkat keterpakaian program pelayanan konseling berbasis nilai-nilai qur'ani dinilai tinggi untuk dapat digunakan sebagai acuan dalam pelayanan konseling.
\end{abstract}

Kata kunci: program pelayanan konseling qur'ani, pribadi, social, karier, akademik 


\section{INTRODUCTION}

College system has to implement the three principles of higher education, that is to say teaching, research, and community service, or better known as the tri dharma of higher education (Law Number 20 concerning the National Education System, Part Four, Article 24, Paragraph 2., 2003). Higher education involves a shift towards a larger, more impersonal structure, and involves interactions with peers that are more diverse both in terms of geographical background and in terms of ethnicity, as well as increasing pressure to achieve good performance, career and values. (Santrock, 2009). From this statement, it can be understood that the purpose of education in higher education system is far more complex than primary and secondary education

Studying in higher education requires good adjustments, especially for first-year students, where they must be able to adjust to life patterns inside and outside of campus, both adjusting to academic problems and to non-academic problems (Winkel \& Hastuti, 2006). Likewise with students at the next level, they are required to be able to adapt to the obligations that must be met, such as attending face-to-face lectures in a disciplined manner, arranging lectures and final assignments (undergraduate-thesis and thesis), obeying the code of ethics of higher education, mutual respect between fellow campus residents, arrange and complete all forms of administrative and financial aspects. In the lecturing process from the beginning of the semester to the end, college students are very vulnerable to get involved with problems, either It has to do with theirselves or other parties (universities), due to their inability to behave and act wisely.

The factors that cause problems for college students are revealed through several research results, such as the gap between college student expectations and the performance or services provided by higher education (Husnayetti, 2012); academic burden, in the form of learning activities such as completing a lot of tasks which require a long time to do the task, lectures in class, exams, achievement competitions with classmates, failure in the learning process, and conflicts of interest (Rakhmawati et al., 2014); living far from parents/family and financially (Legiran et al., 2015); work part time and participate in organizations (Raharjo, 2014); orientation and information about the climate and the demands of learning on campus, effective learning strategies in SKS, principles of learning in Higher Education, learning comfortability, skills to solve learning problems, increased learning motivation and mastery of language of instruction (Fiah, n.d.; Sujadi \& Setioningsih, 2018). The researchers are generally identified these various problems at the State Islamic Institute of Kerinci. These problems indicate that college students need to be given intervention in the form of counseling services.

Counseling services in Higher Education must at least be carried out clearly and systematically. Although the legal basis for implementing Guidance and counseling in higher 
education is not as complete and detailed as the BK (Counseling guidance) service in the Elementary and Secondary Education Unit, several regulations indicate that the Guidance and Counseling service is an important element in the organization of higher education (Sujadi, 2018).

The current problem is that there are still many higher educations that do not have counseling institutions for college students who need help in terms of personal, social, learning and career aspects. For some high education that already have the units/institutions, not all of them have clear standard operating procedures. As a result, college students who have problems are quite confused to seek professional help, so some of them are more prefer to share their feelings to their friends and even on social networking sites. (Sujadi, 2019) .

Though several studies prove that guidance and counseling services are needed in Higher Education (Fiah, n.d.). Handling of learning problems through the counseling guidance process is in great demand and more effective in improving learning achievement (Hayati \& Sujadi, 2018; Ismaya \& Abduloh, 2015). College students are also need a specific counseling place so that the counseling activity can run efficiently, effectively and pleasantly (Ismaya \& Abduloh, 2015).

Some of the formats for implementing Guidance and Counseling services are generally almost the same in every higher education, that is to say, focusing on diminishing academic/learning problems by using a number of service formats and using certain approaches. Remembering and considering that IAIN Kerinci is an Islamic High Education, the development of a qur'ani valuesbased counseling program is considered more appropriate.

Counseling theory that is added and strengthened with an Islamic perspective will greatly help the counselor's work to deal with the demands of religious clients (Diniaty, 2013). Counseling based on the values of the Al- Qur'an is expected to provide a reference in focusing the goals, assumptions and work procedures comprehensively, because this approach focuses more on the lives of the wider individual, namely the life in this world and the life in the hereafter. (Suherman, 2012). Some literature studies are also explain that the counselor's ability to analyze spiritual issues and include these elements in the counseling relationship will be a significant component of the counseling process (Bullis, 1996; Fukuyama \& Servig, 1999; Richards \& Bergin, 2000).

The guidance and counseling service program developed, is not only implemented by lecturers majoring in guidance and counseling with counseling education and professional counselor education background. Moreover, based on the researcher's perspective, the counseling process will involve religious lecturers who have proficiency and capability to internalize qur'ani values in the process of counseling. Based on the background of the problem, the purpose of this research is to formulate a counseling service program based on qur'ani values that is appropriate according to the 
expert; and describe the level of use of the qur'ani values-based counseling service program to overcome college students' problems.

\section{METHOD}

\section{Study Design}

This research uses a development research design. In this study, a guidance and counseling program based on qur'ani values is developed. Based on the characteristics of several existing models, researchers tend to choose the ADDIE model (Analysis, Design, Development, Implementation, and Evaluation) as a reference in this study, because the ADDIE model uses the basics of a general, systematic and gradual framework so that each element has a interconnectedness with one another.

\section{Participants}

The technique used to determine test subjects for expert validation and product usability testing is purposive sampling Product validation involves 3 experts, while product trials involve 3 professional counselors.

\section{Instrument}

This study uses a questionnaire aimed at experts to collect data regarding the validation of the program that is being developed and to the counselor to collect program usage data. The grids to validate the program include: vision and mission, description of needs, objectives, program components, operational evaluation plan, budget; while the program's level of use grids include: planning, implementation and evaluation. All questionnaires used a likert scale of five answer choices.

\section{Statistical Analysis}

Descriptive analysis is used to describe the characteristics of the score distribution of each respondent in the validation activities of the counseling program and testing the usability of the program. Furthermore, Kendall concordance is used to test whether the assessment given by each expert shows a pattern that tends to match or not to the program arranged. In addition, testing process whether the assessment given by each counselor shows a pattern of assessment that tends to match or not to the usability of the product that has been developed. 


\section{RESULTS}

Analysis

The program of Qur'ani values-based counseling service for college students is developed based on observable conditions in the field regarding the analysis of student needs and the condition of higher education.

Design

The initial design of the program of Qur'ani values-based counseling service for Kerinci IAIN college students is outlined in the six sections of program: CHAPTER I. Preliminary; CHAPTER II. Strategic Issues and Development Strategies of IAIN Kerinci; CHAPTER III. Problems of College Students in Kerinci IAIN; CHAPTER IV. Guidance and counseling; CHAPTER V. Qur'ani Values-Based Counseling Services Program for IAIN Kerinci College Students; and CHAPTER VI. Conclusion.

Development

This development phase is carried out through three types of activities, that is to say, research product development, research instrument development, and product revision. The results of the expert assessments of all aspects are collected and used as a reference in making revisions to the products that are prepared, so that a formulation of a program is considered to be appropriate for college students to use and operationalized by counselors in the field. The results of expert validation with regard to the assessment of the next program are presented in the following Table

Table 1. Expert Validation Data

\begin{tabular}{clrrrrrl}
\hline \multirow{2}{*}{ No } & \multirow{2}{*}{ Aspect } & \multicolumn{3}{c}{ Expert Score } & \multirow{2}{*}{$\boldsymbol{\Sigma}$} & \multirow{2}{*}{ Average } & Category \\
\cline { 3 - 6 } & A & B & C & & & \\
\hline 1 & Rational & 23 & 21 & 22 & 67 & 22.33 & Very Proper \\
2 & Vision and mission & 10 & 9 & 10 & 29 & 9.67 & Very Proper \\
3 & Description of Requirement & 9 & 10 & 10 & 29 & 9.67 & Very Proper \\
4 & Goal & 12 & 13 & 13 & 38 & 12.67 & Very Proper \\
5 & Component Program & 34 & 34 & 33 & 101 & 33.33 & Proper \\
& Average & & & & $\mathbf{2 6 4}$ & $\mathbf{8 8}$ & Very Proper \\
\hline
\end{tabular}

* Eligibility categories are compared with the ideal percentage of each aspect assessed in the product

Based on Table 1 it can be seen that the assessment given by experts on the program is very proper with an average score of 88 . That is, experts provide a positive assessment of the program being developed, both in terms of rational, vision and mission, description of needs, objectives and program components. The program is considered to be implemented by counselors in providing qur'ani values-based counseling services to college students of IAIN Kerinci.

To find out more about the results of the assessment regarding the research product developed, a statistical test was carried out to find out whether there was an alignment of the ratings 
between each validator regarding the contents of the program. The results of data processing can be seen in Table 2 .

Table 2. Results of Kendall Concordance Significance Towards Experts

\begin{tabular}{ccccc}
\hline Aspect & Mean Rank & Kendall's W & $\chi^{2 \text { count }}$ & $\chi^{2 \text { table }}$ \\
\hline 1 & 10.83 & & \\
2 & 14.17 & & \\
3 & 4.17 & & \\
4 & 14.17 & & \\
5 & 10.83 & & \\
6 & 14.17 & & \\
7 & 10.83 & & \\
8 & 10.83 & & \\
9 & 14.17 & & \\
10 & 7.50 .14 & & \\
11 & 14.17 & & \\
12 & 7.50 & & \\
13 & 14.17 & & \\
14 & 14.17 & & \\
15 & 4.17 & & \\
16 & 14.17 & & \\
17 & 7.50 & & \\
18 & 4.17 & & \\
19 & 14.17 & & \\
20 & 4.17 & & \\
\hline
\end{tabular}

The number of $\mathrm{N}$ items being valued is 20 . If $\mathrm{N}$ is greater than 7 , a significance test of $\mathrm{W}$ is performed using the chi-square distribution approach $(\chi 2)$ with $\mathrm{db}=\mathrm{N}-1$. For that we need to find the $\chi^{2}$ value by utilizing the SPSS Version 22 calculation results.

Based on these calculations, it is known that the calculated chi-square count $>$ chi-square table value $(33.483>30.14)$ at $\alpha=.05(\mathrm{db}=\mathrm{N}-1)$. This means that there is alignment between expert judgments of the product being assessed. The value of $\mathrm{W}$ indicates that the assessment given by the experts is at a level of strong relationship. This can be proven by looking at $\mathrm{W}$ value of .587.

\section{Implementation}

The data presented in this section is a continuation of a series of product development research after the product development and revision process. Small group test subjects are three counselors with the aim of providing an assessment of the aspects of use in the program being developed. 
The data presented in this activity are data relating to the counselor's response to the program's level of use. The following is a description of the data from the counselor's assessment of the program's level of use.

Table 3. Data of Usage Results

\begin{tabular}{|c|c|c|c|c|c|c|c|}
\hline \multirow{2}{*}{ No } & \multirow{2}{*}{ Aspect } & \multicolumn{3}{|c|}{ Counselor Score } & \multirow[b]{2}{*}{$\Sigma$} & \multirow{2}{*}{ Average } & \multirow{2}{*}{ Category } \\
\hline & & $\overline{\mathbf{A}}$ & B & $\mathrm{C}$ & & & \\
\hline 1 & Planning & 13 & 12 & 13 & 38 & 12.67 & Height \\
\hline 2 & Implementation & 31 & 30 & 31 & 92 & 30.67 & Very High \\
\hline 3 & Evaluation & 22 & 22 & 22 & 66 & 22 & Very High \\
\hline \multicolumn{5}{|c|}{ Average } & & 65.33 & Very High \\
\hline
\end{tabular}

* Usability categories are compared with the ideal percentage of each aspect assessed in the product

Based on Table 3 it can be seen that the overall assessment given by the counselor on program usage is very high with an average score of 65.33 . That is, the counselors gave a positive assessment of the presence of counseling services. Counselors can use the program well, it can be seen in terms of planning, implementation, and evaluation which is in the category of very high usability.

Furthermore, to find out more about the results of the assessment regarding the research product developed, a statistical test was conducted to find out whether there was an alignment of the assessment between each counselor. Following are the results of the data processing using the SPSS Version 22 program.

Table 4. Results of Kendall Concordance Significance Test Towards Counselors

\begin{tabular}{ccccc}
\hline Aspect & Mean Rank & Kendall's W & $\chi^{2 \text { count }}$ & $\chi^{2 \text { table }}$ \\
\hline 1 & 10.33 & & & \\
2 & 5.33 & & & \\
3 & 5.33 & & \\
4 & 12.67 & & & \\
5 & 10.33 & .577 & 24.244 & \\
6 & 5.33 & & \\
7 & 5.33 & & \\
8 & 7.67 & & \\
9 & 7.83 & & \\
10 & 7.83 & & \\
11 & 10.17 & & \\
12 & 5.33 & & \\
13 & 3.67 & & \\
14 & 10.17 & & \\
15 & 12.67 & & \\
\hline
\end{tabular}

Based on the data presentation in Table 4, it is known that the total number of $\mathrm{N}$ as assessed aspects is 15. To determine the alignment level of expert judgment, it is carried out using the $c h i$ square distribution approach with $\mathrm{db}=(\mathrm{N}-1)$. Based on the above calculation, it is known that the 
calculated chi-square count $>$ chi-square table value $(24,244>23.68)$ at $\alpha=.05(\mathrm{db}=\mathrm{N}-1)$. This indicates that there is harmony between the counselors' assessment of the assessed product. The value of $\mathrm{W}$ indicates that the assessment given by the counselor is at a level of strong relationships. This can be proven by seeing the $\mathrm{W}$ value of .577 as a very strong and positive relationship level.

\section{Evaluation}

The evaluation stage is a stage that aims to assess the overall aspects of the use of the program being developed. Evaluation activities in this stage, that is to say, getting responses from counselors related to development efforts and the existence of the products offered.

Responses from counselors who were the subject of product development research generally revealed that the qur'ani values-based counseling service program was quite positive.

\section{DISCUSSION}

The research product produced in this research is a qur'ani values-based counseling service program to overcome the problems of IAIN Kerinci college students. In developing this product, the authors provide guidance of the steps contained in the ADDIE model, namely analysis, design, development, implementation, and evaluation. From the results presented in the development stage it is known that the program that was compiled has reached very proper criteria by experts. This is proven by the overall average value of 88 products and It is in the very feasible category.

The feasibility value given by the experts is a value based on objectivity towards the contents/basis contained in the program. The objectivity can be proven by looking at the test results statistically using the significance test of Kendall concordance coefficient. From the test results, It is known that the alignment level of the given assessment indicates a strong relationship between experts, that is to say, a $\mathrm{W}$ value of .587 .

Furthermore, programs that have been validated by experts are getting better after getting an assessment from the counselor as the user. This argument can be proven from the counselor's average rating of 65.33 . This can be interpreted that the program developed has shown very good results to be accepted and utilized by the counselor. Therefore, all parts of the research product assessed as good and suitable to be applied in IAIN Kerinci.

The qur'ani values-based counseling service program is needed in the organization of higher education. The problem is not only found in middle and high school students, but It includes all components, elements and levels. The various problems experienced by college students will obstruct the attainment of harmony in life, as a result, It will disrupt the effective life. 
There are several requirements that must be met in the implementation of guidance services in higher education (Afandi, 2012), that is to say: First, general requirements, relating to the completeness of institutions that support the efforts of guidance services which includes: (1) availability of the guidance and counseling office, (2) the counseling guidance office must be coordinated by a guidance expert, (3) the costs and facilities required (4) the contents of the guidance program must be adjusted to the characteristics of the developmental period experienced by students in general , (5) guidance services must reach out to all students.

Second, related to employment, which includes: (1) the presence of a counselor, (2) the presence of experts in analyzing the results of psychological testing, (3) the presence of advisory lecturers or trustee lecturers (this name is adjusted to the characteristics of each high education), (4) Active role of expert lecturers of certain course, (6) the presence of administrative guidance staff.

Third, relating to the specific requirements of the advisory lecturer: (1) the willingness of the advisory lecturers to attempt to conduct close relations with their college students that are not only limited to the in-class meeting, (2) the willingness of the advisory lecturer to give sufficient attention to each of the college students, (3) the willingness of the advisory lecturers to spare their time, (4) the willingness of advisory lecturers to carry out various educational activities, (5) the distance of psychological ties that are not too far and not too close to their college students, (6) the willingness of advisory lecturers to maintain the secrets of their college students' personal issues.

The program of qur'ani values-based counseling service developed by researchers follows the standard components of the BK program. Due to there is no availability of standard for the BK program component in higher education, the researchers adapted the BK service program component in Primary and Secondary Education as stated in Permendikbud No. 111 of 2014. The structure of the program includes: rational, vision and mission, description of needs, goals, program components, service areas, operational plans, theme/topic development, evaluation/reporting/follow-up and budget. Another study explained that the counseling program in higher education contained at least components, including: rationale, vision and mission of guidance and counseling services, functions and objectives of guidance and counseling services, the scope of guidance and counseling services, organization and management of guidance and counseling services (Fiah, n.d.).

The problem that occurs is that there are still many higher educations that prioritize academic aspects of education by ignoring the importance of the development of college students psychological ascpects. As a result we often found many students who are unable to complete their lectures, dropped out of the campus, engage in brawls, use of illegal drugs, promiscuity, and other forms of maladaptive behavior (Sujadi et al., 2018). 
Some higher educations that already have counseling service units also do not have a clear reference in its implementation, so the service units are limited to "between exist and non-exist", only functioned as an administrative complement for the purposes of accreditation. Though several studies prove that guidance and counseling services are needed in Higher Education (Ismaya \& Abduloh, 2015). A study revealed that students really need guidance and counseling services in order to relieve and develop aspects of learning, personal-social, career, psychological, emotional and spiritual needs (Fiah, n.d.). College students are also need a specific counseling place so that the counseling activity can run efficiently, effectively and pleasantly (Ismaya \& Abduloh, 2015).

Specifically, at IAIN Kerinci, as one of the Islamic higher education institutions in Indonesia, with all Muslim lecturers, education staff and students, the application of counseling programs based on qur'ani values is considered very appropriate and relevant to each individual's own personality.

Counseling based on Qur'ani values is the activity of providing guidance, lessons and guidelines to individuals who ask for guidance (clients), in terms of how a client should be able to develop the potential of his mind, mentality, faith and belief and can overcome their life problematics and his life it selves in a good and right way, independently which is paradigmatic to the Qur'an (Adz-Dzaky, 2001). Counseling theory that is added and strengthened with an Islamic perspective will greatly help the counselor's work to deal with the demands of religious clients (Diniaty, 2013). Counseling should broaden the horizons of views and extend scope, deepen the insights that are not merely psychosocio-cultural centric, but are able to capture human existence in this world and in the hereafter as creatures of Allah. He further explained that the approach of counseling based on the values of the Al- Qur'an will provide a reference in focusing the goals, assumptions and procedures in a comprehensive manner, because this approach focuses more on the lives of the wider individual, namely the life in this world and the life in the hereafter (Suherman, 2012). Some literature studies are also explain that the counselor's ability to analyze spiritual issues and include these elements in the counseling relationship will be a significant component of the counseling process (Bullis, 1996; Fukuyama \& Servig, 1999; Richards \& Bergin, 2000; Sujadi, 2015).

\section{CONCLUSION}

The formulation of a program of qur'ani values-based counseling service that is being developed was declared feasible and could be utilized by the counselor to assist college students in developing their effective lives. The limitations of this development which include the respondents in this study are still limited; then the product development in this research only reaches the aspect of usability, not yet at the stage of testing its effectiveness to college students through a series of experimental studies. 


\section{REFERENCES}

Adz-Dzaky, M. H. B. (2001). Psikoterapi dan Konseling Islam: Penerapan Mefode Sufistik. Fajar Pustaka Baru.

Afandi, M. (2012). Pengembangan Program Layanan Bimbingan Dosen Penasehat Akademik di UIN Suska Riau. Kutubkhanah, 15(1), 27-37.

Bullis, R. . (1996). Spirituality in Social Work Practice. Taylor \& Francis.

Diniaty, A. (2013). Urgensi Teori Konseling dan Perspektifnya dalam Islam Menjawab Tuntutan Konseling Religius di Masa Depan. Jurnal Al-Ta'lim, 1(4), 312-323.

Fiah, R. El. (n.d.). Urgensi Layanan Bimbingan dan Konseling di Perguruan Tinggi (Studi terhadap Kebutuban dan Pencapaian Tugas-tugas Perkembangan Mabasiswa untuk. Menyusun Rancangan Implementasi Layanan Bimbingan dan Konseling di LAIN Raden Intan Lampung).

Fukuyama, M. A., \& Servig, T. D. (1999). Integrating Religion and Spirituality into Counseling: A Comprehensive Aprroach. Brooks/Cole.

Hayati, I. R., \& Sujadi, E. (2018). Perbedaan Keterampilan Belajar Antara Siswa IPA dan IPS. Tarbawi : Jurnal Ilmu Pendidikan, 14(1), 1-10.

https://doi.org/https://doi.org/10.32939/tarbawi.v14i1.250

Husnayetti, H. (2012). Tingkat Kepuasan Mahasiswa dan Proses Belajar Mengajar di Perguruan Tinggi X. Jurnal Liquidity, 1(2), 115-124.

Ismaya, B., \& Abduloh, A. (2015). Efektifitas Layanan Bidang Bimbingan \& Konseling dalam Meningkatkan Prestasi Belajar Mahasiswa Prodi Pendidikan Bahasa Inggris FKIP Unsika. Jurnal Ilmiah Solusi, 2(5), 33-57.

Legiran, L., Azis, M. Z., \& Bellinawati, N. (2015). Faktor Risiko Stres dan Perbedaannya pada Mahasiswa Berbagai Angkatan di Fakultas Kedokteran Universitas Muhammadiyah Palembang. Jurnal Kedokteran Dan Kesehatan, 2(2), 197-202.

Undang-undang Nomor 20 Tahun 2003 tentang Sistem Pendidikan Nasional, Bagian Keempat, Pasal 24, Ayat 2., (2003).

Raharjo, R. (2014). Problem dan Solusi Studi Mahasiswa Semester Tua. Nadwa, 8(2), 313-336.

Rakhmawati, I., Farida, P., \& Nurhalimah, N. (2014). Sumber Stress Akademik dan Pengaruhnya Terhadap Tingkat Stress Mahasiswa Keperawatan DKI Jakarta. JKep, 2(3), 72-84.

Richards, P. S., \& Bergin, A. E. (2000). Handbook of Psychotherapy and Religious Diversity. American Psychological Association.

Santrock, J. (2009). Adolescence Seventh Edition. Erlangga.

Suherman, U. (2012). Pendekatan Konseling Berbasis Nilai-nilai Al Qur'an: Tinjauan Filosofis Tentang Hakikat dan Peran Manusia. Seminar Internasional Konseling MALINDO-2.

Sujadi, E. (2015). Konseling Pancawaskita untuk Membentuk Problem Focused Coping. Jurnal Konseling Dan Pendidikan, 3(1), 14-24. https://doi.org/https://doi.org/10.29210/112100

Sujadi, E. (2018). Kode Etik Profesi Konseling Serta Permasalahan dalam Penerapannya. Tarbawi : Jurnal Ilmu Pendidikan, 14(2), 69-77. https://doi.org/10.32939/tarbawi.v14i2.298

Sujadi, E. (2019). Penerapan Play Therapy dengan Menggunakan Permainan Tradisional untuk Meningkatkan Keterampilan Sosio Emosional. Jurnal Bimbingan Dan Konseling Terapan, 3(1), 14-24. https://doi.org/http://dx.doi.org/10.30598/jbkt.v3i1.892

Sujadi, E., Meditamar, M. O., Ahmad, B., \& Rahayu, A. (2018). Pengaruh Konsep Diri dan Locus of Control Terhadap Motivasi Berprestasi. Educational Guidance and Counseling Development Journal, 1(1), 32-51. https://doi.org/http://dx.doi.org/10.24014/egcdj.v1i1.4808

Sujadi, E., \& Setioningsih, L. (2018). Perbedaan Locus Of Control Ditinjau dari Etnis. Jurnal Bimbingan Dan Konseling Terapan, 2(2), 128-138. 
https://doi.org/http://dx.doi.org/10.30598/jbkt.v2i2.371

Winkel, W., \& Hastuti, S. (2006). Bimbingan dan Konseling di Institusi Pendidikan. Raja Grafindo Persada. 